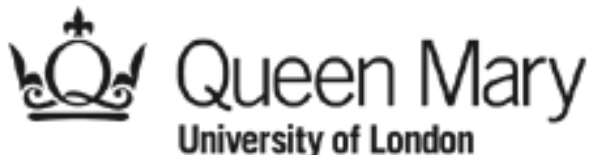

Queen Mary University of London, School of Law

Legal Studies Research Paper No. 65/2010

\section{Countering the dangers of online pornography - shrewd regulation of lewd content?}

\author{
Julia Hornle
}




\section{Countering the dangers of online pornography - shrewd regulation of lewd content?}

\section{Introduction}

This Article will detail how the UK has responded to the greater risks posed by illegal online content by successively extending the reach of the substantive criminal laws and by taking preventative measures. It will focus on the example of laws on obscene content on the internet and associated online behaviour.

For this purpose, in Part I, the Article will briefly set out, by way of background, the criminal laws on obscene content and how they have been applied and interpreted in internet cases. As will be demonstrated, the provisions have proved sufficiently flexible to deal with new ways of accessing and distributing content by new technologies.

Nevertheless, the article will argue that the internet has not only created greater opportunities for the distribution of legal content it has also created new ways for illegal content to reach a wider audience. The second part of the Article will briefly outline why the internet has created a greater risk in this respect.

In Part III it is argued that the UK has responded to these greater risks by extending the reach of the criminal law far beyond its pre-internet limits. Here the focus will be on the new laws on extreme pornography and the criminalisation of virtual child abuse images, notably the criminalisation of non-photographic pornographic images of children. These new laws raise difficult questions as to where to draw the line between risk reduction and civil liberties. I base my arguments on the premise that any restrictions of civil liberties by the criminal law must be justified by the prevention of harms, rather than public morality. This principle will show where the UK legislation has overshot the mark.

Considering the greater risk posed by the internet, it becomes increasingly clear that focusing on criminal law is insufficient. The multitude of crimes committed and limited resources for enforcement necessitate more effective crime prevention and enforcement strategies. These preventative steps cannot be taken by the government alone, but must involve all stakeholders of civil society and, in particular, internet intermediaries. Part IV will outline some of the steps taken in the UK in this respect. 
The Article will conclude with an evaluation of the measures discussed in the previous parts.

\section{Part I}

\section{Background: summary of the criminal law on pornography}

In the UK the standard for criminality of pornography is obscenity- this not only includes obscenely indecent, sexually explicit materials, but also depictions of extreme violence without sexual connotations. ${ }^{1}$ Section 1 of the 1959 Obscene Publications Act sets out the main test of obscenity: 'if its effect (...) taken as a whole is such to tend to deprave and corrupt persons who are likely, having regard to all relevant circumstances, to read, see or hear the matter contained or embodied in it.' It is for the jury to decide whether material falls within that definition. In deciding whether content is likely to deprave or corrupt, the jury may take into account the likely audience of the material, for example if this includes children the threshold will be lower than if the audience is less impressionable. ${ }^{2}$

The Acts apply to obscene articles and an article is defined as 'any description of article containing or embodying matter to be looked at or both, any sound record and any film or other record of a picture or pictures'. ${ }^{3}$

The Obscene Publications Act 1959, Section 1 (3) defines 'publication' as distributing, circulating, selling, letting on hire, giving, lending, showing, playing, projecting or broadcasting ${ }^{4}$ it. In 1994 the Criminal Justice and Public Order Act 1994 added 'or where the matter is data stored electronically', transmitting that data. ${ }^{5}$ This latter provision would cover the transmission of an electronic file containing obscene content without the need for storing the material on a tangible object (such as a CD or printing it as a hardcopy). This includes circulating the material by email or making it available for downloading from a server. ${ }^{6}$ However, for the publication offence to apply to a website

\footnotetext{
${ }^{1}$ The two main general pieces of legislation are the Obscene Publications Acts 1959 and 1964

${ }^{2}$ DPP v Whyte [1972] AC 849, 863B

${ }^{3}$ Section $1(2)$

${ }^{4}$ Section $1(4)-(6)$

${ }^{5}$ Sch.9 Para. 3

${ }^{6}$ L Edwards, J Rauhofer and Majid Yar 'Recent Developments in UK Cybercrime Law' Chapter 20 in Y Jewkes, M Yar Handbook of Internet Crime (Willan Publishing Portland 2010) 413-436, 414, see also (in respect of child abuse images): Fellows and Arnold [1997] 2 All ER 548 holding that the act of making material available for downloading (pull technology) is publication
} 
containing obscene materials, more than a negligible number of viewers must have seen it. ${ }^{7}$ The maximum prison term on indictment was three (now five) years. ${ }^{8}$

The Acts target the dissemination and publication of obscene articles, which means that the mere possession of an obscene article is not a criminal offence. ${ }^{9}$ The Act prohibits the (commercial or non-commercial) publication and possession for gain. ${ }^{10}$ Hence, non-commercial, private possession is not an offence.

By contrast, images which show the sexual abuse of children are not only obscene in the sense that they can corrupt public morals- they are in addition the record of the abuse of a child and hence the law takes a stricter approach. The Protection of Children Act 1978 makes it a criminal offence in England to take, make, distribute, show or publish any indecent photograph of a child. ${ }^{11}$ This legislation was amended to criminalise the mere possession of such photographs by the Criminal Justice Act $1988^{12}$, on the basis that a photograph of this nature is a record of the abuse of an actual child and that demand for such material fuels abuse of children. For the purposes of the Act, a child is a person under the age of 18- the age of protection was raised in $2004 .{ }^{13}$ The Act makes clear that references to a photograph include an indecent film and a copy of an indecent film or photograph ${ }^{14}$ and that the word 'photograph' includes data stored on a computer disc or by other electronic means which is capable of being converted into an image. ${ }^{15}$ The maximum punishment was a term of imprisonment of three (now ten) years. ${ }^{16}$ The maximum punishment for the possession offence was six months' (now five years') imprisonment. ${ }^{17}$

This summary of the law shows the state of play in the mid-1990s when the internet was about to give easy and convenient access to a whole host of legal and illegal materials to a wide audience. The raises the question of how has the criminal law dealt with the technical challenges posed by this new form of technology. For example what amounts to 'possession' or 'publication' in a computer mediated environment? This will be the concern of the next section.

\section{How the criminal law on obscene content has adapted to new technology}

\footnotetext{
${ }^{7}$ ibid para 31

${ }^{8}$ Section 2 (1) (b) Obscene Publications Act 1959

${ }^{9}$ L Edwards, J Rauhofer and Majid Yar 'Recent Developments in UK Cybercrime Law' Chapter 20 in Y Jewkes, M Yar Handbook of Internet Crime (Willan Publishing Portland 2010) 413-436, 414

${ }^{10}$ Section 1 (1) Obscene Publications Act 1964, now s. 2 (1) of the Obscene Publications Act 1959

${ }^{11}$ Section 1 (a); for Scotland see s. 52 Civic Government (Sc) Act 1982

${ }^{12}$ Sections 160 (England) and 161 (Scotland)

${ }^{13}$ Section 2 (3); by the Sexual Offences Act 2003

${ }^{14}$ Section 7 (2) Protection of Children Act 1978

${ }^{15}$ Section 7 (4) inserted by the Criminal Justice and Public Order Act 1994

${ }^{16}$ Section 6 (2)

${ }^{17}$ Section 160 (2A) and (3) of the Criminal Justice Act 1988
} 
This section will argue that the courts-in typical common law fashion- had no trouble in adapting the legislation on criminal obscene content through interpretation in order to capture new ways of possessing, making or publishing such illegal content. The courts have simply subsumed new ways of doing things under the existing legal provisions and thereby widened the reach of these provisions. Hence the internet has created no legal lacuna in this respect and case law has more than filled any gaps by taking a wide approach to statutory interpretation.

For example in the case of $R v$ Fellows and Arnold $^{18}$ the first appellant had uploaded child sex abuse images on a database which he made available to others who had been given a password in order to access the database via the internet. The second appellant had uploaded pictures to the database and downloaded others. The Court said that a file on a database which can be displayed on screen and printed out constitutes a copy of a photograph. ${ }^{19}$ The Court also had no difficulty in finding that the uploading of such images constituted possession with a view to their being distributed or shown and publication, even though distribution on the internet takes place through copying. ${ }^{20}$

Atkins v DPP; Goodland v DPP ${ }^{21}$ concerned the legal treatment of viewing child abuse images online where the defendant had not deliberately stored the images on the computer. If the image is not deliberately saved on a computer disc but contained in a browser cache (as a result of viewing the image online), would that be sufficient for the 'possession' offence? The Queen's Bench held that the possession offence requires knowledge- so since in this case, Atkins, the defendant did not know that his computer contained the images in the cache, he was not guilty of the possession offence. ${ }^{22}$

The courts have further developed the criminal law in respect of the possession offence. If someone opens an email attachment and does not know that this contains images of child abuse, then neither the 'making' nor the 'possession' offence would be applicable. ${ }^{23}$

In Porter the Court of Appeal held that if a file had been deleted from a computer and the recycling bin emptied, a person is only still in possession of the file if they have the technical knowledge to retrieve the file, as possession requires custody and a certain amount of control. ${ }^{24}$

\footnotetext{
${ }^{18}$ [1997] 1 Cr App R 244

${ }^{19}$ At 254: 'It contains data, not visible to the eye, which can be converted by appropriate technical means into a screen image and into a print which exactly reproduces the original photograph from which it was derived. It is form of copy which makes the original photograph, or a copy of it, available for viewing by a person who has access to the disc. There is nothing in the Act which makes it necessary that the copy should itself be a photograph within the dictionary or the statutory definition, and if there was, it would make the inclusion of the reference to a copy unnecessary. So we conclude that there is no restriction on the nature of a copy, and that the data represents the original photograph, in another form.'

${ }^{20}$ ibid

${ }^{21}$ Atkins v DPP; Goodland v DPP [2000] 2 Cr App R 248 (QB)

22262

${ }^{23}$ Smith and Jayson [2002] EWCA Crim 683; Humphreys [2006] EWCA Crim 640; in relation to the possession offence, s.160 (2) (c)of the Criminal Justice Act 1988 additionally provides a defence

${ }^{24}$ [2006] EWCA 560
} 
As to the question of what constitutes making in the online context, in Atkins v DPP; Goodland $v$ $D P P$, the Queen's Bench held that the deliberate saving of an image file to a computer would amount to 'making' such an image ${ }^{25}$. Hence, the mere downloading of a picture amounts to the 'making' of that picture and is therefore caught by the provisions targeting the production of illegal content rather than its mere possession. ${ }^{26}$ This wide interpretation of 'making' is troublesome as downloading content for private use is more akin to possession than the production of such content and the making offence carries a higher sentence than possession. Likewise, in the case of $R v$ Perrin, a case concerning obscene images other than child abuse images, the Court held that both the downloading and uploading of electronic files may constitute publication under the Obscene Publications Act $1959 .^{27}$

In $R v$ Harrison $^{28}$ the Court of Appeal clarified the mens rea requirements for the 'possession' and 'making' offences and extended the 'making' offence even further. In this case the defendant was a regular customer of pornographic websites- these websites delivered 'pop-up' advertisements featuring child sex abuse images, which he claimed he was not interested in and did not deliberately store on his computer, but which left automatic traces on his computer's hard disc. The Court of Appeal rejected the argument that it was the website designer who made these pop-up images. ${ }^{29}$ The Court held that viewing an image on a pop-up advertisement constituted 'making', since the computer automatically copied the image to parts of the hard drive. The mental element was satisfied if the defendant knew that the images would pop-up and once viewed were automatically saved. ${ }^{30}$ The Court of Appeal also held that in the case of an image merely viewed but not deliberately saved, the defendant could be said to have possession of it, albeit for a very short time, if he knew he had possession. ${ }^{31}$ The Court of Appeal found that both the making and possession offences could be committed by accessing a pornographic website with legal pictures which caused a window with an illegal picture to pop-up automatically, if the defendant knew that this would happen. ${ }^{32}$

From this brief summary of the case law, it is apparent that in respect of the online activities of browsing, downloading and uploading, the Courts have held that these activities can constitute possession (for example under Section 160 of the Criminal Justice Act 1988) and the 'making' of such images (for example under Section 1 (a) of the Protection of Children Act 1978 as amended by the Criminal Justice and Public Order Act 1994) or publishing (for example under the Obscene Publications Act 1959). Thus the Courts have been prepared to

\footnotetext{
${ }^{25}$ Atkins v DPP; Goodland v DPP [2000] 2 Cr App R 248 (QB) 260 "to make" meant "to cause to exist, to produce by action, to bring about" according to the Court. The prosecution prosecuted for the making offence, because time had run out for the possession offence, at 252

${ }^{26}$ Atkins v DPP; Goodland v DPP [2000] $2 \mathrm{Cr}$ App R 248 (QB) relying on the Court of Appeal decision in $R v$ Bowden [2000]1 Cr App R 438 which held that downloading images or printing them out is 'making' them

${ }^{27}$ [2002] EWCA Crim 747, paras 18, 51-52

${ }^{28}$ [2008] 1 Cr App R 29

${ }^{29}$ Para 17

${ }^{30}$ Para 17

${ }^{31}$ Para 20

${ }^{32}$ Paras $17-20$
} 
interpret these prohibited activities in a flexible manner, without regard to the technical fineries of internet communication and transmission of electronic files. While this means that the case law has filled any gaps in the legislation, expansion of the law by judicial interpretation raises concerns with a view to the principle of nullum crimen sine lege ${ }^{33}$. Essentially the courts have confounded the possession and the making offences. This wide interpretation of the publication and making offences should have reduced the need for further extension of the possession offences (discussed below). ${ }^{34}$

In addition to adapting the criminal law on obscene content to new modes of accessing and distributing this content via the internet, the substantive reach of these provisions themselves have been increased dramatically in the UK in recent years. Before examining this development, the next part will briefly explore why the government may have been moved to introduce such far-reaching provisions by new legislation.

\section{Part II}

\section{The risks of the information society}

In this part I will sketch what I term the 'risks of the information society'. Much has been written about the internet and the inherent risk that it is used for disseminating and accessing illegal content. ${ }^{35}$ I will just very briefly summarise this discussion by splitting it under three main headings. The 'risks of the information society' (as well as the internet's positive transformative effects for information access and freedom of expression) are due to three factors (i) the 'borderless' nature of the internet, (ii) the complexity of the technology layers and (iii) its accessibility, efficiency and convenience.

The cross-border nature of the internet and the intangible nature of the content mean that the offender can target illegal content (for example by uploading materials and making them thus

\footnotetext{
${ }^{33}$ For a discussion of the principle in the context of English law see A Ashworth Principles of Criminal Law $\left(6^{\text {th }}\right.$ Edition Oxford University Press 2009) 58-62

34 J Rowbottom 'Obscenity Laws and the Internet: Targeting the Supply and Demand' [2006] Criminal Law Review 97-109, 104

${ }^{35}$ B Sandywell 'On the Globalisation of Crime: the Internet and new Criminality' Chapter 3 in Y Jewkes, M Yar Handbook of Internet Crime (Willan Publishing Portland 2010) 38-66, 40, 43-44; I Walden Computer Crimes and Digital Investigations (Oxford University Press 2007) 58-59, 84-85; U Sieber 'General Report on Internet Crimes' for the $18^{\text {th }}$ International Congress of the International Academy of Comparative Law in Washington DC; Sections D and E; more specifically in the context of child pornography see S Ost Child Pornography and Sexual Grooming (Cambridge University Press 2009) 48-54 and Y Akdeniz Internet Child Pornography and the Law (Ashgate Aldershot 2008) 1 et sequi
} 
available) from one jurisdiction to persons accessing the materials located in another jurisdiction. This leads to the twin problems of jurisdiction ${ }^{36}$ and cross-border enforcement. ${ }^{37}$

The jurisdictional problems have directly led to the expansion of the criminal law by penalising possession of certain illegal content, where previously only the active publication or distribution of such materials was a criminal offence, as will be discussed in Part III. ${ }^{38}$

Secondly the complexity of the technology makes the investigation and prosecution of crimes resource and expertise intensive and, hence expensive. One illustration for this is tracing the way messages are routed across the internet for example where criminals are spoofing their identity or location to avoid detection. Another example is the technological arms-race between the police and sophisticated criminals (who use encryption and peer-to-peer file sharing technologies instead of websites to distribute illegal content for example). The possibility of simultaneous interaction also opens up new possibilities of criminality (for example criminals planning their crime in a chat room or child abusers grooming children on social networking sites, as discussed below).

The third factor is the widespread availability of and access to the internet, for viewing, for downloading and for uploading of content. The convenience and asocial nature of access (without leaving the home or office) and the perceived anonymity may lower inhibitions and encourage certain persons to seek out illegal content, where they would not have bothered to obtain it in the offline world. ${ }^{39}$ Prosecution figures for the offence of possessing child pornography have risen

\footnotetext{
${ }^{36}$ This problem has led the English courts to adopt a broader test on finding jurisdiction in criminal cases- instead of focusing on the last act to make the offence complete the courts now adopt a more holistic approach in the form of the 'substantial measure test'- the courts accept jurisdiction if a substantial measure of the activities constituting the crime take place in England, see $R v$ Sheppard and Whittle [2010] EWCA Crim 65 (CA) and J Hörnle "The Internet and Criminal Jurisdiction" 21 (1) Computers \& Law [April-May 2010] 11-12

${ }^{37}$ A discussion of this topic is outside the scope of this Article, but the interested reader can be referred to $S$ Brenner, B-J Koops 'Approaches to Cybercrime Jurisdiction' [2004] 4 (1) Journal of High Technology Law 1-46; I Walden Computer Crimes and Digital Investigations (Oxford University Press 2007) Chapter 5; J Hörnle Crossborder Online Gambling Law \& Policy (Elgar Cheltenham 2010) Chapter 3

${ }^{38}$ See the Consultation on the Criminal Justice and Immigration Bill, introducing the new offence of possession of extreme pornography, para 32 http://webarchive.nationalarchives.gov.uk/20100418065544/http://www.homeoffice.gov.uk/documents/consextreme-porn-3008051/cons-extreme-pornography2835.pdf?view=Binary

${ }^{39}$ Consultation on the Criminal Justice and Immigration Bill, introducing the new offence of possession of extreme pornography, para 32 see $\mathrm{fn} 38$; see also the Consultation on the Possession of Non-Photographic Visual Depictions of Child Sex Abuse, pp. 4-6 http://webarchive.nationalarchives.gov.uk/20100418065544/http://www.homeoffice.gov.uk/documents/cons2007-depiction-sex-abuse2835.pdf?view=Binary; the Times reports on investigation identifying 200 suspects in 2007, see http://www.timesonline.co.uk/tol/news/uk/crime/article1951385.ece, see also Y Akdeniz Internet Child
} 
sharply in proportion to the widespread access to the internet and the dissemination of such content in newsgroups, through websites or peer-to-peer technology. ${ }^{40}$

That the easy availability of images of child sex abuse is a disturbing development has been shown by Operation Ore. This investigation followed from the prosecution of a couple in the US who had run a website portal featuring child sex abuse images and the FBI handed over the payment records of UK residents who had downloaded images from the website to the UK authorities. By 2006 the UK authorities had received the details of 7,100 suspects (sic) and Operation Ore had resulted in 2,400 convictions. While some of the convictions were later challenged as being unsafe on the basis that the defendants had become victims of credit card fraud ${ }^{41}$, these figures are nevertheless disconcerting. The police had found child sex abuse images on the computers of most suspects seized as a consequence of this investigation. The shockingly large number of suspects and resulting convictions in this case arising from one single internet portal, seems to indicate, sadly, that the consumption of this heinous content through the internet is a much more prevalent and widespread phenomenon than one may have thought. In a similar vein, the Guardian newspaper has reported that a substantial number, a total of almost 1000 persons, were convicted of publishing or possessing such content in $2007 .{ }^{42}$

While ultimately it is probably impossible to quantify the 'risks of the information society' in a meaningful and objective way, these statistics confirm the suspicion that the internet leads to an increase in the dissemination of child sex abuse and other obscene content. The high number of people viewing and downloading such content may have impacts on human behaviour (propensity to violence, child abuse etc) and challenge the practical feasibility of law enforcement.

Certain high profile criminal cases which were widely reported in the media, such as the Coutts murder trial $\left.\right|^{43}$ (which will be discussed further below) have also increased the public perception that the internet enables the dissemination of criminally obscene materials leading to deviant behaviour

Pornography and the Law (Ashgate Aldershot 2008) 6 and A Murray 'The Reclassification of Extreme Pornographic Images' (2009) 72 (1) Modern Law Review 73-90, 73

${ }^{40}$ See statistics 1980-2004 in Y Akdeniz Internet Child Pornography and the Law (Ashgate Aldershot 2008) 24-26

${ }^{41}$ http://www.guardian.co.uk/uk/2009/jul/02/web-child-abuse-inquiry-challenge and had only looked at legal adult pornography, see J Rowbottom 'Obscenity Laws and the Internet: Targeting the Supply and Demand' [2006] Criminal Law Review 97-109, 104

${ }^{42} 782$ of the publication/making offence and 185 of the possession offence, see http://www.guardian.co.uk/society/2010/jun/27/bulger-killer-charge-crime, more statistics on child sex abuse images on the internet can be found at http://www.icmec.org/missingkids/servlet/PageServlet?LanguageCountry=en X1\&Pageld=1742

${ }^{43}$ http://en.wikipedia.org/wiki/Graham Coutts 
in the real world and that 'something should be done'. As so often, this call for 'something should be done' leads to the expansion of the reach of the criminal law, as will be discussed in the next part.

\section{Part III}

\section{Extending the reach of the criminal law}

In this Part III it will be demonstrated how the UK has responded to the dangers of the information society by substantially expanding the reach of the criminal law in the area of obscene content. The law in this area has been extended in four respects: (i) the creation of new inchoate offences, (ii) extending the types of activities or types of materials within the scope of the criminal offences, (iii) increasing the sentence for deterrent effect and (iv) preventative measures.

\subsection{Inchoate offences}

Inchoate ${ }^{44}$ offences are incomplete offences, in the sense that the main criminal act has not yet been carried out or the main criminal result has not yet been brought about. ${ }^{45}$ Inchoate offences criminalise what are merely preparatory acts (in relation to the main offence as previously defined)relying heavily on the intention (mens rea) of the defendant to carry out the main criminal act or to bring about the main criminal result, even where there is as yet no criminal harm. Therefore, (depending on the offence in question) they are frequently criticised as mere 'thought' crimes, especially if the defendant's preparatory conduct is ambiguous in the sense that it can have more than one explanation. Inchoate offences allow more flexibility to the prosecution and allow earlier action by law enforcement. In other words, they add significant strings to the prosecution's bow and their main purpose is harm prevention. ${ }^{46}$ One example in relation to the 'information society risks' described in this Article is the group of 'grooming' offences created by the Sexual Offences Act 2003, which will be discussed next.

\section{Grooming Offences}

It seems that child abusers use internet applications such as chat rooms and social networking sites (such as Facebook, Bebo and MySpace) to contact children and teenagers and to obtain a false sense of trust (often by posing as a teenager themselves). Child sex abusers lure the child into disclosing personal details (such as her address, mobile phone number or school), to encourage the child to send indecent pictures and to use these indecent pictures or other details to manipulate and to

\footnotetext{
44 'Inchoate' means 'just began' or 'undeveloped' see A Ashworth Principles of Criminal Law (6 ${ }^{\text {th }}$ ed Oxford University Press 2009) 437

${ }^{45}$ ibid

${ }^{46}$ More detailed arguments justifying or discrediting inchoate criminality can be found in A Ashworth Principles of Criminal Law (6 $6^{\text {th }}$ ed Oxford University Press 2009) 468
} 
blackmail her further into a sinister spiral of more revealing pictures or even to arrange a meeting and to carry out physical abuse. ${ }^{47}$

In order to encounter this threat, it was felt necessary to create a range of new offences ${ }^{48}$ in the Sexual Offences Act 2003: arranging or facilitating the commission of a child sex offence in Section $14^{49}$ and meeting a child following sexual grooming in Section 15. Section 15 applies if the defendant has met or communicated with a child ${ }^{50}$ (for example through chat or instant messaging at a distance) on at least two occasions and subsequently intentionally meets the child, or travels with the intention of meeting her or arranges to meet her in any part of the world, or the child travels with the intention of meeting the defendant. ${ }^{51}$ The preparatory communication ('grooming') need not be of any sexual nature and may include an entirely platonic 'relationship' (at least on the face of it)..$^{52}$ The conduct, grooming, is not defined in the Act. ${ }^{53}$

The defining requirement is that the defendant's intention must be to do anything to or in respect of the child which involves the commission of a relevant sexual offence in any part of the world. ${ }^{54}$ They are inchoate offences, focusing largely on the risk of certain types of behaviour and the intention of the defendant. ${ }^{55}$ The maximum sentence is a prison term of 10 years. ${ }^{56}$

If we assume that an adult 'innocently' communicates twice with a child in a chat room and then travels to meet the child, these actions in themselves are not harmful. The difference between an innocent and a criminal act is the intention (mens rea) of the defendant. ${ }^{57}$ Since this is an internal factor, mens rea may be difficult to prove and can only be inferred from the circumstances. Unusual circumstances may lead to false inferences. This may put innocent citizens at risk.

Hence, the trouble with these new offences is that they criminalise what may, on the face of it, be innocent conduct before any indecent pictures are taken or sexual activity is carried out. In fact no child sex offence may ever be carried out.

\footnotetext{
${ }^{47}$ See some of the educational materials produced by CEOP http://www.ceop.gov.uk and S Ost Child Pornography and Sexual Grooming (Cambridge University Press 2009) 49

${ }^{48}$ The proposed Directive on combating the sexual abuse, sexual exploitation of children and child pornography COM (2010)94 final Article 6 also contains a grooming offence

${ }^{49}$ Section 14 (1): 'A person commits an offence if (a) he intentionally arranges of facilitates something that he intends to do, intends another person to do or believes another person to do, in any part of the world and (b) doing it will involve the commission of an offence under sections 9-13' (child sex offences).

${ }^{50} \mathrm{~A}$ child is defined for the purposes of this provision as a person under 16 and the defendant must not reasonably believe that the person is 16 or older, s. 15 (1) (c) and (d)

${ }^{51}$ Section 15 (1) (a)

${ }^{52}$ HG v The Queen [2010] EWCA Crim 1693 (CA) Para 16; see also S Ost Child Pornography and Sexual Grooming (Cambridge University Press 2009) 72

${ }^{53}$ S Ost Child Pornography and Sexual Grooming (Cambridge University Press 2009) 72

${ }^{54}$ Section 15 (1) (b)

${ }^{55}$ L Edwards, J Rauhofer and Majid Yar 'Recent Developments in UK Cybercrime Law' Chapter 20 in Y Jewkes, M Yar Handbook of Internet Crime (Willan Publishing Portland 2010) 413-436, 420

${ }^{56}$ Section 15 (4); however an indeterminate sentence may be given for public protection reasons see Attorney General's Reference (No 3 of 2006) [2006] EWCA Crim 695

${ }^{57}$ S Ost Child Pornography and Sexual Grooming (Cambridge University Press 2009) 73
} 
Moreover an attempt, itself an inchoate offence, may be charged even where the defendant has not yet made any preparations to meet the victim. This places criminality even further away from actual harmful conduct.

For example in $R v$ Robson ${ }^{58}$ the defendant had asked a sex worker on more than one occasion to find him a girl of 12 or 13 to engage in sexual activities and he was charged with the Section 14 offence of arranging of facilitating the commission of a child sex offence. The Court of Appeal found that his conduct may amount to an attempt of 'arranging' and 'facilitating', even where the person requested did not agree to carry out the request (and in fact informed the police). ${ }^{59}$

While this case did not involve remote communication via the internet it illustrates the breadth of the offence of 'facilitating and arranging'. In fact following this interpretation of Section 14 in $R v$ Robson, if a person communicates remotely with a child (in a chat room or using email or instant messaging for example) and requests (perhaps insists) to meet the child, this may be sufficient for charging the Section 14 offence, provided he has the requisite intention and there may be no need to rely on the narrower offence outlined in Section 15.

Moreover, an attempt of Section 15 is regularly charged where it is impossible to carry out a child sex offence, where the defendant is communicating with an undercover police officer who poses as a child on a social networking site, for example. In $R v S$ the defendant had entered a social networking site and made contact with another user who called herself Helen and stated that she was 14 years old- they communicated over a period of 17 days and the conversations turned sexual in nature. The defendant invited 'Helen' to meet him and no doubt was surprised -when he was arrested at the agreed meeting point- to find out that he had been conversing with an adult police officer. His sentence was reduced on appeal to 16 months' imprisonment. ${ }^{60}$

In addition, if there is not sufficient evidence to charge the accused with attempt, an application may be made for a Sexual Offences Prevention Order (SOPO) ${ }^{61}$ under Section 104 of the Sexual Offences Act 2003. For this it is sufficient that the accused has been cautioned for a relevant offence, which could prevent him to use chat rooms or social networking sites. ${ }^{62}$ Likewise, if the defendant has been convicted of an attempt, even if there have been no previous similar offences, a SOPO may be ordered. ${ }^{63}$

\footnotetext{
${ }^{58}$ [2009] EWCA Crim 1472; see also $R$ v Jordan [2006] EWCA Crim 3311 where the defendant was convicted of a Section 14 offence (not an attempt but the full offence ) on almost identical facts 
The aim of the inchoate offences in Sections 14 and 15 of the Sexual Offences Act 2003 is to criminalise conduct before any harm has been done to a child- hence the goal is harm prevention. This has been justified by the need to protect children from harm when interacting onlineconsidering the gravity of this risk, preventative action is required. However it can also be argued that this extension of the criminal law puts innocent citizens at risk and it is at least questionable whether the law has found the right balance between protecting children and protecting citizens from unfair accusations.

In the same preventative mode, the criminal law has been extended to cover new types of obscene content, which will be examined in the next section.

\subsection{Extending the actus reus}

\subsubsection{Possession offences}

The traditional compromise between freedom of expression and protection of morals and the protection of dignity has been to prohibit the publication and distribution of certain forms of obscene content, but to tolerate the private, non-commercial possession of such materials, for example in the Obscene Publications Acts 1959 and $1964 .{ }^{64}$ The prosecution of possession offences also is more difficult, more resource intensive and requires a greater invasion of privacy ${ }^{65}$. The greater invasion of privacy and greater restriction of the access to information are the reasons why the law drew a line between dissemination and private possession, criminalising the former but not the latter.

The problem with basing criminality on publication is that it creates problems in the borderless environment of the internet. If obscene content is produced, uploaded and hosted in a foreign jurisdiction and only downloaded and 'consumed' in the local jurisdiction, and if mere possession of obscene materials is no offence in the local jurisdiction, suppression of obscene content in the local jurisdiction may be difficult, as local enforcement agencies may have no jurisdiction against foreign suppliers or, in any event, cannot directly enforce against such suppliers. ${ }^{66}$ Therefore the law has

\footnotetext{
${ }^{64}$ L Edwards, J Rauhofer and Majid Yar 'Recent Developments in UK Cybercrime Law' Chapter 20 in Y Jewkes, M Yar Handbook of Internet Crime (Willan Publishing Portland 2010) 413-436, 414; J Rowbottom 'Obscenity Laws and the Internet: Targeting the Supply and Demand' [2006] Criminal Law Review 97-109, 98

${ }^{65}$ In the sense that it requires the search of a suspect's private space and seizure of a private computer, intrusive and possibly covert investigation techniques

${ }^{66}$ The English courts, as we have seen above under 3., however have interpreted the downloading of child abuse images as 'making' such images, so that the distinction between mere passive possession and active production of such images has been blurred in any event. So even if possession of such material was not criminalised, the downloading would still be punishable as an act of 'making'.
} 
been amended to criminalise the mere possession of certain types of content. ${ }^{67}$ As we have seen above ${ }^{68}$ the possession of child sex abuse images has already been criminalised in 1988 , before widespread access to the internet. Recently however the possession offences have been extended considerably to cover new types of content, in order to deal with the specific challenges posed by the internet.

\subsubsection{Criminalisation of the possession of new types of content}

\section{Extreme Pornography}

The Criminal Justice and Immigration Act 2008, which came into force on 26. January 2009, introduced a new offence of possessing an extreme pornographic image. ${ }^{69}$ While this new offence applies to online and offline extreme pornography, the driving factor behind its introduction was the easy access and convenient availability of such material through the internet. ${ }^{70}$ In that sense the availability of 'extreme pornography' to broad sections of the population is a new quantitative problem, which did not exist in the 'pre-internet' days. In this sense, the internet has enabled a new distribution channel which can be exploited by unscrupulous entrepreneurs who make a large profit from this type of content. ${ }^{71}$ It would be naive to regard the issues raised by this type of content merely as an issue of the freedom of speech of individual groups who engage in certain types of sexual practices and who exchange this type of material without commercial motive.

One of the factors behind the proposal of this legislation was the evidence presented in the trial of Coutts, the convicted murderer of school teacher Jane Longhurst. He had downloaded and consumed extreme pornography before he committed the murder. ${ }^{72}$

Extreme pornography would, in many instances, fall under the Obscene Publications Acts, but as has been explained above, these Acts do not criminalise the mere possession of such material, hence the requirement for the new legislation. ${ }^{73}$ As has been pointed out above such material may be commercially produced and hosted and published abroad where it may be largely out of the reach of UK law enforcement. Since therefore the supply side cannot be controlled it was felt necessary to restrict demand though the introduction of this new offence. ${ }^{74}$

\footnotetext{
${ }^{67}$ See also J Rowbottom 'Obscenity Laws and the Internet: Targeting the Supply and Demand' [2006] Criminal Law Review 97-109, 104

${ }^{68}$ Section 2

${ }^{69}$ Section $63(1)$

${ }^{70}$ Consultation on the Criminal Justice and Immigration Bill, introducing the new offence of possession of extreme pornography, para 32 see $\mathrm{fn} 38$

${ }^{71}$ http://www.dailymail.co.uk/news/article-511969/Snuff-movies-website-shut-Mail-Sunday-probe.html

72 http://www.guardian.co.uk/commentisfree/2008/nov/27/response-coutts-crime-pornography-murder

${ }_{73}$ But see fn 66

${ }^{74}$ I Walden Computer Crimes and Digital Investigations (Oxford University Press 2007) 137
} 
Extreme pornography must both be pornographic and extreme. ${ }^{75}$ This means that the material must be of such a nature that it must reasonably be assumed to have been produced solely or principally for the purpose of sexual arousal. ${ }^{76}$ In relation to a series of images (such as a film), the images must be seen in their whole context and an image may not be found pornographic by virtue of it being part of a narrative, even if by itself it might have been found pornographic. ${ }^{77}$

For it to be regarded as being extreme the image must be obscene ${ }^{78}$ and it must depict in an explicit and realistic way

'(a) an act which threatens a person's life or

(b) an act which results, or is likely to result, in serious injury to a person's anus, breasts or genitals,

(c) an act which involves sexual interference with a human corpse, or

(d) a person performing an act of intercourse or oral sex with an animal (whether dead or alive),

and a reasonable person looking at the image would think that any such person or animal was real. ${ }^{79}$

Hence, extreme pornography covers realistic depictions of so-called 'snuff videos', particular types of violent pornography, necrophilia and bestiality. The Act does not define the term 'serious injury' which leaves the question open whether this refers to actual bodily harm $(\mathrm{ABH})$ or grievous bodily harm (GBH). In some ways the act is also under-inclusive, as a depiction of violence in a sexual context causing GBH to parts of the body not mentioned in subsection (b) without being an act threatening a person's life under (a) would not be included in the possession offence.

Section 64 contains an exclusion for films which have been classified by the British Board of Film Classification (BBFC), unless they are taken out of context in such a way that they become pornographic. Of course, this does not mean that extreme pornographic films subject to the classification system are exempt. The BBFC has to take into account Section 63 and refuse to classify a film if it falls within the definition of extreme pornography.$^{80}$ One of the difficult issues arising from the Act will be to distinguish between pornography (intended for sexual arousal) and art.

For films, ultimately this issue will be left to the BBFC and, in a case before the court, a jury. But the perennial problem here is that 'beauty lies in the eyes of the beholder'. For example could a series

\footnotetext{
${ }^{75}$ Section $63(2)$

${ }^{76}$ Section 63 (3) and it is this criterion which would distinguish it from art

${ }^{77}$ Section 63 (4) and (5)

${ }^{78}$ Section 63 (6) (b): 'grossly offensive, disgusting or otherwise of an obscene character'

${ }^{79}$ Section $63(7)$

${ }^{80}$ Section 64 (6), similar provisions are contained in the Coroners and Justice Act 2009 in respect of nonphotographic pornographic images of children in Section 63
} 
of images, such as the murder scene in Hitchcock's thriller 'Psycho', not constitute pornography to a certain set of eyes (while it may constitute art to a more innocent set of eyes)?

Section 65 provides a defence if (a) the person had a legitimate reason for possessing the image, (b) that the person had not seen the image and did not know and had no cause to suspect it to be extreme pornography ${ }^{81}$ or $(\mathrm{c})$ that the image was sent without request and that the person did not keep it for an unreasonable amount of time. ${ }^{82}$ Section 66 provides a further defence for certain consensual acts, which (for the obvious reason that an animal cannot consent to such an act) does not apply to bestiality.

For the Section 66 defence, the defendant has to show that the act depicted did not inflict any nonconsensual harm on any person and in the case of necrophilia, that the act did not involve a real corpse. ${ }^{83}$ Non-consensual harm is either harm to which a person cannot consent to by law ${ }^{84}$ or harm to which a person in fact has not consented to. ${ }^{85}$ But the defence is only available to the persons depicted, not to a person who does not appear in the images (such as a director or producer or a person possessing this content). ${ }^{86}$ Therefore this defence only applies to 'homemade' pornography, which does not leave the circle of those acting in it.

In other words, the offence applies to depictions of realistic, but simulated activities (even if no harm was inflicted) and to consensual activities (where harm ${ }^{87}$ was inflicted with the actual consent of the person harmed) if the depiction is in the possession of a person not acting in the image.

The punishment for the possession of images of violent pornography as defined in section 63 (a) and (b) is a maximum prison sentence of three years and/or a fine. ${ }^{88}$ The punishment for possession of necrophilia or bestiality defined in section 63 (c) and (d) is a maximum prison term of two years and/or a fine. ${ }^{89}$

Most ordinary people (including the author!) regard extreme pornography as disgusting and extremely offensive. Although I have not conducted empirical research into this area, I assume that most extreme pornography depicts violence by men against women in a sexual setting and if the new provisions contribute to preventing the social acceptability of such material, this seems an

\footnotetext{
${ }^{81}$ This may be a defence for a hosting provider

${ }^{82}$ The same defences exist against a charge of possession non-photographic pornographic images of children in section 64 of the Coroners and Justice Act 2009

${ }^{83}$ Section 65 (2)

${ }^{84}$ This would include killing or grievous bodily harm (GBH). But it would probably also include actual bodily harm $(\mathrm{ABH})$, such as the harm inflicted in $R v$ Brown [1994] $1 \mathrm{AC} 212(\mathrm{HL})$, where the House of Lords held that a person cannot consent to the infliction of $\mathrm{ABH}$ in the context of sado-masochistic practices between men in private. This would also include sex with a person below the age of consent.

${ }^{85}$ Section 65 (3)

${ }^{86}$ Section 66 (2) (a)

${ }^{87}$ In the sense of 'serious injury to a person's anus, breasts or genitals'

${ }^{88}$ Section 67 (2)

${ }^{89}$ Section 67 (3)
} 
important step to protect the bodily integrity and dignity of women (or other subjects of extreme pornography).

At the same time, it is questionable whether what a majority regards as not acceptable should be the guiding principle for drawing the line between lawful and criminal content. In a liberal society the only justification for criminalizing certain conduct should be whether this conduct is harmful to interests which should be protected by the criminal law ('harm principle'). ${ }^{90}$ This restriction of the concept of public morality is based on John Stuart Mill's theory on moral rights ${ }^{91}$ and HLA Hart's treatise on the interplay between law, liberty and morality ${ }^{92}$ and Joel Feinberg's work ${ }^{93}$. It should also be pointed out that the principle that the criminal law should only protect against harms, but not enforce matters which should be left to private morality was behind the Wolfenden Report of 1957 recommending the abolition of homosexuality offences between consenting adults. ${ }^{94}$

John Stuart Mill has described this principle in this manner: 'That principle is that the sole end for which mankind are warranted, individually or collectively, in interfering with the liberty of action of any of their number is self-protection. That the only purpose for which power can be rightfully exercised over any member of a civilized community against his will is to prevent harm to others. ${ }^{95}$

HLA Hart has argued in support of the conclusions of the Wolfenden Report that a distinction must be made between an affront to public decency and acts taking place in private which are merely immoral according to conventional morality. ${ }^{96} \mathrm{He}$ refers to Mill's harm principle that coercion may justifiable be used to prevent harm to others ${ }^{97}$ and expressly points out that the mere distress caused by knowing that other persons engage in immoral acts is insufficient 'harm' ${ }^{98}$. The value of individual liberty demands that the acceptance of the principle that an individual may do what he wants, even if others are distressed unless there are good reasons for prohibiting the conduct. ${ }^{99}$ These good reasons are harm prevention.

\footnotetext{
${ }^{90}$ See also the discussion in relation to the new offence criminalising non-photographic pornographic images of children S Ost 'Criminalising Fabricated Images of Child Pornography: a Matter of Harm or Morality?' (June 2010) 30 (2) Legal Studies 230-256, 240-245, S Ost Child Pornography and Sexual Grooming (Cambridge University Press 2009) 103 and C Nowlin 'The Protection of Morals Under the European Convention for the Protection of Human Rights and Fundamental Freedoms' (2002) 24 (1) Human Rights Quarterly 264-286, 265, 271

91 JS Mill 'On Liberty' in JS Mill Utilitarianism, On Liberty, Considerations on Representative Government (Orion London 1993)

${ }^{92}$ HLA Hart Law, Liberty and Morality (Oxford University Press 1963)

93 J Feinberg The Moral Limits of the Criminal Law: Harm to Others (Oxford University Press 1984)

${ }^{94}$ Report of the Committee on Homosexual Offences and Prostitution $1957 \mathrm{Cmd} 247$ paras 13. and 14., stating that the law's function is to preserve public order and decency and to protect citizens from 'what is offensive and injurious', but that the function of the law is not to intervene in the private lives of citizens in order to 'enforce any particular pattern of behaviour'. The Report argues that morality based on religion and culture is wider in scope than the criminal law and hence a distinction has to be made between morality and the law.

95 JS Mill fn 91 p.78

${ }^{96}$ HLA Hart Law, Liberty and Morality (Oxford University Press 1963) 45

${ }^{97}$ Ibid 46

${ }^{98}$ Ibid 46-47

${ }^{99}$ Ibid 47
} 
The harm principle has also been applied in a Canadian Supreme Court case of $1992 .{ }^{100}$ The Court held that pornography could only be outlawed in order to avoid harm to society ${ }^{101}$ and that the freedom of speech could not be restricted simply by reference to a standard of public and sexual morality ${ }^{102}$. However in this case the Court upheld the Canadian legislation on the basis that there is a 'substantial body of opinion that holds that the portrayal of persons being subjected to degrading or dehumanizing sexual treatment results in harm, particularly to women and therefore to society as a whole ${ }^{\prime 103}$.

Joel Feinberg has further refined the concept of harm which justified the imposition of criminal penalties. He describes the harm principle as follows: 'state interference with a citizen's behavior tends to be morally justified when it is reasonably necessary (...) to prevent harm or the unreasonable risk of harm to parties other than the person interfered with' ${ }^{104}$

Feinberg defines 'harm' through the notion of interest thus: 'one person harms another (...) by invading, and thereby thwarting or setting back, his interest. ${ }^{105}$ However he also posits that not every harm is a legal wrong: 'that is why the harm principle needs to be supplemented by an elaborate set of mediating maxims, interest-rankings, principles of justice, and the like, before it can be applied to real legislative problems. ${ }^{106} \mathrm{He}$ argues that only wrongs that are setbacks to recognized interests fall within the harm principle. ${ }^{107}$

In principle one can think of three possible harms which Section 63 attempts to address: (i) the actual infliction of grievous bodily harm $(\mathrm{GBH})$ or actual bodily harm $(\mathrm{ABH})$ or the murder of a real person; (ii) where no actual bodily harm has been inflicted (for example in a simulated scene) the images may encourage or stimulate actual infliction of bodily harm on a real person in the offline world and (iil) harm to human dignity and public morality.

As to (i), if extreme pornography depicts the real infliction of GBH on or the murder of a real person, the harm to bodily integrity justifies the prohibition. As to (ii) Section 63 (7) expressly stipulates that the image must portray in an explicit and realistic way the extreme acts listed. But there is no requirement that the acts depicted must be real, in other words the legislation does apply to simulated conduct, provided it looks real. So if the conduct is simulated, a justification of the criminalization would have to rely on (ii) as a ground for justification. It is arguable that the causal link between the consumption of simulated extreme pornography and committing such acts

\footnotetext{
${ }^{100} R$ v Butler [1992] DLR (4 $\left.{ }^{\text {th }}\right) 449$ mentioned by C Nowlin 'The Protection of Morals Under the European Convention for the Protection of Human Rights and Fundamental Freedoms' (2002) 24 (1) Human Rights Quarterly 264-286, 266

${ }^{101} R$ v Butler [1992] DLR $\left(4^{\text {th }}\right) 449,477$ (Justice Sopinka)

102 at 476

${ }^{103}$ At 467

${ }^{104}$ Feinberg fn 93 p. 11

${ }^{105}$ Feinberg fn 93 p. 34

${ }^{106}$ Feinberg fn 93 p. 36

${ }^{107}$ Ibid
} 
in real life in the offline world is difficult to prove. ${ }^{108}$ By the same token it is also difficult to disprove such a causal link. ${ }^{109}$ The internet has made it much more convenient to consume extreme pornography in great quantities. This may in a person, who is predisposed, lead to the nurturing of an obsession leading to the commission of violent offences in the real world. As Leslie Wilson has put it eloquently in her commentary in the Guardian on the Coutts trial:

"But what I saw at Coutts' trial was the story of a man who nurtured and encouraged that part of himself by visiting pornographic internet sites - sites that went way beyond images of women being bound up and gagged. They featured violent sex, strangulation, rape and torture. Coutts downloaded images from these sites - as I remember, an enormous number in the days immediately preceding the murder (...)The human psyche is so much more malleable than it's comfortable to think." ${ }^{110}$

Therefore I argue in this article that we should err on the side of caution. The stakes are too high: violent sexual crime committed against a person leaves serious harm and widespread distribution of extreme pornography creates a real risk (even though impossible to quantify) of such harm. Hence (ii) offers a justification for restricting the possession of such material by the criminal law.

Finally justification (iii) may be even more controversial- obscene pornography is always an infringement of human dignity and public morality (in terms of being offensive to a majority), but should this be a sufficient ground to criminalise the mere possession of such content? However since the Act only applies to 'realistic' content there would be no need to rely on (iii) as (ii) already provides justification. ${ }^{111}$

A separate issue, but resurrected by this debate on extreme pornography, in the context of sadomasochistic ( $S$ \& $M$ ) practices, is whether a person should be able to consent to $A B H$, especially if it only causes temporary injury. The position under English law is that a person can only consent to $\mathrm{ABH}$ if this is justified by some notion of the public interest (such as sports) and that $\mathrm{S} \& \mathrm{M}$ practices are not in the public interest. The main authority for this position is the House of Lords decision in $R$ $v$ Brown ${ }^{112}$ and the confirmation by the ECtHR in the same case that Member States have a wide discretion to criminalise certain sexual conduct even if carried out in private between consulting adults. Hence according to ECtHR jurisprudence the criminalization of $S \& M$ does not constitute an unjustified infringement of Article 8. By analogy, this may mean that the criminalization of the

\footnotetext{
${ }^{108}$ One of the accusations against the Bill was that it was not based on scientific research, see for example Memorandum by Dr Clarissa Smith et al

http://www.publications.parliament.uk/pa/cm200607/cmpublic/criminal/memos/ucm34102.htm and Memorandum by Backlash http://www.publications.parliament.uk/pa/cm200607/cmpublic/criminal/memos/ucm40502.htm See also the arguments made by Feinberg fn 93 236-240

${ }^{109}$ A Murray 'The Reclassification of Extreme Pornographic Images' (2009) 72 (1) Modern Law Review 73-90, 77-78, 81

${ }^{110}$ See for example the comment in the Guardian http://www.guardian.co.uk/commentisfree/2008/nov/27/response-coutts-crime-pornography-murder

${ }^{111}$ See below under 7 .

${ }^{112}$ Fn 84
} 
possession of images depicting $S \& M$ is not an unjustified restriction of the freedom of speech under Article 10 ECHR. ${ }^{113}$ However, it would have been preferable to exclude trivial harm from the scope of the offence, by expressly limiting its application to the depiction of GBH in section 63 (7) (b) as this would have more clearly based the Act on the harm principle under (i) or (ii).

Furthermore, less justifiable perhaps from a liberal standpoint and the harm principle are the provisions on the possession of images of bestiality- while the production and distribution of such material may cause serious harm to animals so that a prohibition on the making of such material is justified from an animal protection point of view, it is perhaps not justifiable to criminalise the mere possession of such material, especially in a society which allows the private possession of other obscene materials (including images showing violence against persons). Furthermore forms of violent pornography other than those defined in section 63 (such as rape) or even content depicting extreme violence outside a sexual context may be equally harmful, but do not fall within the scope of the Act, which is inconsistent and it is ultimately unclear what the Act tries to achieve at a policy level. ${ }^{114}$

The provisions on extreme pornography have been controversial and are likely to remain so. However in this debate it would make sense to make a clear distinction between, on the one hand, consensual S \& M practices and the issues related to consent to $A B H$ and, on the other hand, the question of harm arising from content depicting realistically more extreme forms of simulated violence (such as so-called 'snuff videos' or images where GBH is portrayed). While a harm based argumentation may not justify the prohibition of the former, it may well do so with the latter.

Similar issues arise in relation to virtual child sex abuse images which will be discussed next.

\section{Virtual Child Sex Abuse Images}

What we are concerned with here is the scope of materials which are covered by the criminal offences of possessing, making and publishing child sex abuse images. In particular, the question arises whether an image which is not a record of child sex abuse (such as a photograph) but a fantasy image should also fall within the scope of the offences.

First, if the image is a so-called 'morphed photograph' depicting the body of an adult and the head of a child, or a photograph of an adult which has been digitally manipulated to represent a child ('pseudo-photographs') should this be included? Secondly should the law criminalise images which are not photographs depicting a real-world scene, but which are pure fantasy pictures, such as drawings (cartoons) or computer generated images (CGI)?

The harm done by such fantasy depictions is (i) that they may promote the acceptability of child sex abuse and encourage persons to engage in sexual activities with children in the real world and

\footnotetext{
${ }^{113}$ Laskey v UK (1997) 24 EHRR 39; see further the discussion in A Ashworth Principles of Criminal Law $\left(6^{\text {th }}\right.$ ed Oxford University Press 2009) 311-314, see also the discussion below under 7.

${ }^{114}$ A Murray 'The Reclassification of Extreme Pornographic Images' (2009) 72 (1) Modern Law Review 73-90, 87-88
} 
nurture their proclivities in this respect (as discussed above in relation to extreme pornography), (ii) that they may be used to 'groom' children and persuade them to engage in sexual activities. ${ }^{15}$

Furthermore, in relation to CGI it has also been suggested that if CGI of child pornography was legal, real child sex abuse images may be converted into $\mathrm{CGI}$ and used to stigmatize and pressurize the victims. Thus there is a possibility that perpetrators of child sex abuse use virtualised images of their abuse in order to groom, molest, victimise and blackmail their real world victims. In other words, in some instances CGI do represent real-world abuse of real children, even though this may not be obvious from the image itself. ${ }^{116}$

However an inclusion of fabricated or fantasy images brings considerable definitional challengeswhere would one draw the line between art and child sex abuse images? ${ }^{117}$ If a picture is pure fantasy how can one conclusively determine the age of the characters depicted? For example, it may be extremely difficult to determine the age of an avatar in a virtual world environment.

Pseudo-photographs have been included in the scope of the offences under the Protection of Children Act 1978 by the Criminal Justice and Public Order Act 1994. A pseudo-photograph is defined as an image whether made by computer graphics or otherwise howsoever, which appears to be a photograph. It is sufficient that the impression is created that the person portrayed is a child. ${ }^{118}$

The Criminal Justice and Immigration Act 2008 included a tracing of a photograph (whether electronic or made by other means) in the scope of the Act. ${ }^{119}$ So where the image is derived by tracing of a photograph it was already included.

Finally, the Coroners and Justice Act 2009 took this one step further and criminalised the possession of non-photographic pornographic images of children (NPPIC). ${ }^{120}$ The image must be grossly offensive, disgusting or otherwise of an obscene character and it must be pornographic (defined in the same way as for extreme pornography). ${ }^{121}$ For the NPPIC to be within the scope of the Act it must focus 'solely or principally on a child's genital or anal region' or portray one of the

\footnotetext{
${ }^{115}$ See also S Ost Child Pornography and Sexual Grooming (Cambridge University Press 2009) 125; Y Akdeniz Internet Child Pornography and the Law (Ashgate Aldershot 2008) 22-23

${ }^{116}$ For a more detailed discussion see S Ost 'Criminalising Fabricated Images of Child Pornography: a Matter of Harm or Morality?' (June 2010) 30 (2) Legal Studies 230-256, 240-245; see also Consultation on the Possession of Non-Photographic Visual Depictions of Child Sex Abuse, pp. 4-6, see fn 39

${ }^{117}$ The same issue of delineation may arise with historical objects, which are of interest because of their historical context, but are also pornographic (at least in their original use)- an example for this would be the Warren Cup (Roman) which was featured in Radio 4's History of the World in 100 Objects depicting sexual activities between men and boys in Greek times

${ }^{118}$ Section 7 (7) and (8) of the Protection of Children Act 1978

${ }^{119}$ Section 7 (4A) Protection of Children Act 1978

${ }^{120}$ Section $62(1)$

${ }^{121}$ Section 62 (2) and (3): 'it must reasonably be assumed to have been produced solely or principally for the purpose of sexual arousal'
} 
sexual acts listed in the legislation. ${ }^{122}$ Hence for non-photographic images the subject-matter of the picture must fall in one of these categories.

As to the question how to determine whether the person depicted is a child the Act merely states the impression conveyed by the image must be that the person shown is a child, or the predominant impression conveyed must be that the person shown is a child despite the fact that some of the physical characteristics shown are not those of a child. ${ }^{123} \mathrm{~A}$ child is defined as a person under $18 .{ }^{124}$

Presumably this definition based on 'impression' is a factual decision for the jury to decide and is hence quite uncertain. For example it may be difficult to decide whether an avatar based pornographic film depicting sexual intercourse (shown, for example in Second Life) depicts a child or an adult. This may make it difficult to clearly distinguish between legal fantasy of sex between adults (virtual pornography) and illegal NPPIC- the required characteristic that the image must be obscene does not help with this distinction, since, if the person depicted seems to be a child, the picture is automatically obscene. The problem here is that impressions of whether an avatar is a child or an adult may be extremely subjective, depending entirely on the state of mind of the observer.

The same defences as for extreme pornography exist against a charge of possession nonphotographic pornographic images of children in section 64 of the Coroners and Justice Act 2009. ${ }^{125}$ The Act does not explicitly criminalise the publication of NPPIC, but this would be an offence under the Obscene Publications Acts 1959 and 1964.

The maximum penalty for the offence is a term of imprisonment of three years and/or a fine. ${ }^{126}$

Cyber-libertarians may argue that such expansion of the criminal law and the resulting restrictions on the freedom of expression and, in particular the freedom to obtain information, are not justified by the risks posed by pseudo- and non-photographic images of child sex abuse. Ultimately the balance depends on one's view of whether a causal link between the consumption of pseudo- and non-photographic images and actual abuse can be made out. ${ }^{127}$ Different societies will come to a different conclusion of this balancing act. ${ }^{128}$

In the UK, in any case the scope of what amounts to images of child sex abuse has been significantly extended- again with the aim of protecting children before any harm has been done to them (or to

\footnotetext{
${ }^{122}$ Section 62 (7): intercourse, oral sex, anal or vaginal penetration, masturbation, bestiality involving or in the presence of a child

${ }^{123}$ Section 65 (6)

124 Section 65 (5)

${ }^{125}$ See text fn 82

${ }^{126}$ Section 66 (2) (b)

${ }^{127}$ See http://www.publications.parliament.uk/pa/cm200809/cmpublic/coroners/memos/ucm1102.htm

${ }^{128}$ In the US the Supreme Court has held in 2002 that rules criminalising virtual child pornography were an unjustified restriction of free speech: Ashcroft v Free Speech Coalition 534 US 234, 122 S Ct 1389
} 
prevent the continuing victimisation of abused children by possessing non-photographic images of their abuse). The Act has been narrowly defined as the image must portray specific items (as described above) so the impact on freedom of expression has been minimised. On the other hand the difficulty of determining the age of a virtual fantasy character and the difficulty of distinguishing between art and pornography may mean that the legislation is problematic.

\subsection{Increasing criminal sanctions for deterrent effect}

The maximum sentences for the offences criminalising obscene content have been significantly increased in recent years. For example, the Criminal Justice and Court Services Act 2000 increased the maximum penalty for the publication of child sex abuse images from three years' to ten years' imprisonment ${ }^{129}$ and the maximum penalty for the possession of such images from six months (on summary trial) to a five years' prison term (on indictment). ${ }^{130}$ The Explanatory Notes to the Act merely state that the government was concerned that the previous penalties did not reflect the seriousness of the offences, which in itself does not explain why the change was necessary. ${ }^{131}$ The Notes however refer to a marked increase of prosecutions for both offences: from 40 (1994) to 116 (1998) for the publication offence and from 53 (1994) to 167 (1998) for the possession offence. ${ }^{132}$ As we have seen above, prosecution figures have increased further since.

Furthermore, the Criminal Justice and Immigration Act 2008 has increased the maximum sentence for the publication of obscene publications under the Obscene Publications Act 1959 from three years to five years. ${ }^{133}$

These two examples illustrate how the punishment for the publication and/or possession of obscene content has been dramatically increased in recent years. These increases have at least partly been driven by the risks associated with the information society (and in particular the convenience of access to such material), as well as an increased awareness about these risks. Others may argue that this increase in protection is the result of a moral panic- a disproportionate response to a greatly exaggerated risk, blown up by the media, the police and government. ${ }^{134}$ Moral panic or not, the particular risks posed by the information society cannot be denied.

\footnotetext{
${ }^{129}$ Section 41 (1)

${ }^{130}$ Section 41 (3)

${ }^{131}$ Para 19, see http://www.opsi.gov.uk/acts/acts2000/en/ukpgaen 20000043 en 1

132 Ibid

${ }^{133}$ Section 71; The Explanatory Notes are silent on the reason for this.

${ }^{134}$ On the moral panic in the area of child pornography, see S Ost Child Pornography and Sexual Grooming

(Cambridge University Press 2009) 148-177
} 


\section{Part IV}

\section{Prevention is better than cure}

Because of the particular risks posed by the information society, which make crimes related to the publication and possession of obscene content more prevalent and also harder to investigate, the call for crime prevention and an approach involving all stakeholders has grown louder. ${ }^{135}$

\subsection{General}

Crime prevention in respect of obscene content has many facets. In the UK, this included the creation of a specialist police agency dealing with child abuse (the Child Exploitation and Online Protection Centre- CEOP) which adopts a multi-stakeholder approach: staff from children charities, payment providers, technology companies and government experts are directly involved in its work. ${ }^{136}$ Secondly, prevention also involves action by payment providers to identify relevant transactions and to prevent the use of their systems to pay for illegal content. ${ }^{137}$ Furthermore, another important aspect in preventing online and offline child sex abuse is to prevent convicted child sex offenders from re-offending. To this end, a court may issue a Sexual Offences Prevention Order (SOPO) ${ }^{138}$, ordering that the offender is registered, preventing him to work with children, imposing regular notification requirements with the police, preventing the offender from approaching nurseries, schools, youth centres etc, and other similar requirements. Clearly here the offenders' interests and those of society have to be carefully balanced. For example, in a recent case ${ }^{139}$, the Court of Appeal held that a SOPO prohibiting a convicted offender from possessing a computer or using the internet except for the purposes of work, study or seeking employment and a prohibition on subscribing to a private internet access account was draconian and disproportionate. The Court of Appeal amended the Order in that the offender had to notify his probation officer of any computer or mobile he possessed and he had to ensure that the computer was able to retain a record of his internet access and to give the probation/other police officer access to such history on demand. Another

\footnotetext{
${ }^{135}$ On the importance of crime prevention and involvement of all stakeholders see N Kozlovski 'Designing Accountable Online Policing' in J Balkin et al Cybercrime (New York University Press 2007) 107-134, 109-114; Y Akdeniz Internet Child Pornography and the Law (Ashgate Aldershot 2008) 225 et sequi

${ }^{136}$ http://www.ceop.gov.uk

137 In the UK a draft law (Bill) was introduced before Parliament on 21. July 2010 to impose penalties on credit and debit card providers for facilitating the downloading of child sex abuse images from the internet. In particular, if this Bill becomes law it would oblige issuers of pre-paid cards to register a person's name and address and take proof of id before issuing a pre-paid card, Credit Regulation (Child Pornography) Bill, Bill No 61 Session 2010/2011

${ }^{138}$ Section 104 Sexual Offences Act 2003

${ }^{139} R$ v Mortimer (Jason Christopher) [2010] EWCA Crim 1303
} 
preventative measure is to vet individuals working with children online: the Safeguarding Vulnerable Groups Act 2006, Schedule 3 introduced a requirement that moderators of public interactive communication services, which are likely to be used wholly or mainly by children (such as a social networking site or chat room for children) must be vetted as being fit to work with children and registered with the Independent Safeguarding Authority. ${ }^{140}$

While it is impossible for lack of space to discuss or even list all preventative measures here, the remainder of this Article will focus on just one preventative measure and this is the removal of illegal obscene content at source (if hosted in the UK) and the filtering of content at access provider level to reduce the number of child sex abuse images reaching UK internet users.

\subsection{Internet Watch Foundation}

In the UK, filtering at internet access level has been put into effect in respect of child sexual abuse content notified to and checked by police trained operators employed by the Internet Watch Foundation (IWF), a private, not-for profit company. ${ }^{141}$

The IWF operators decide which URLs are included on the list, which typically contains between 500 and 800 URLs at any one time and is updated twice a day to ensure all entries are live. ${ }^{142}$ URLs are assessed in accordance with UK criminal law and the Guidelines issued by the UK Sentencing Guidelines Council. ${ }^{143}$ The list is designed to block only specific URLs, not the whole domain name, to reduce over-blocking. ${ }^{144}$ This blacklist is the basis for the filtering implemented by British Telecommunications PIc and by most other UK Internet Service Providers (ISPs) on a self-regulatory basis. ${ }^{145}$

The filtering is employed only in respect of child sex abuse images and only for websites, not other types of content (such as peer-to-peer file sharing). An appeal against the accuracy of the assessment is provided. ${ }^{146}$

The Internet Watch Foundation states on its website about the effectiveness of its filtering initiative:

"this initiative can help to diminish the re-victimisation of children by restricting opportunities to view their sexual abuse and may disrupt the accessibility and supply of images to those who

\footnotetext{
${ }^{140}$ Schedule 3

${ }^{141} \mathrm{http} / / / \mathrm{www}$.iwf.org.uk/public/page.148.437.htm

${ }^{142}$ http://www.iwf.org.uk/public/page.148.htm

${ }^{143}$ http://www.iwf.org.uk/public/page.148.htm

${ }^{144}$ http://www.iwf.org.uk/public/page.148.htm

${ }_{145} \mathrm{http} / / /$ www.guardian.co.uk/technology/2004/jun/06/childrensservices.childprotection or http://news.bbc.co.uk/1/hi/technology/4689386.stm

${ }^{146}$ http://www.iwf.org.uk/public/page.148.htm
} 
seek them out. Unfortunately, blocking cannot put an end to offenders abusing children nor can it effectively deny determined criminals who are actively seeking such material." ${ }^{147}$

However the remit of the IWF is wider than child sex abuse content. Within the remit are (i) images of child sex abuse hosted anywhere in the world, (ii) criminally obscene adult content hosted in the UK, (iii) incitement to racial hatred hosted in the UK and (iv) non-photographic child sexual abuse images hosted in the UK.

If the content is hosted by an ISP in the UK it will notify the ISP concerned and the police or CEOP and the content will be taken down at source. Since most of the ISPs are members of the IWF, they cooperate in this and the process is institutionalized. In any case an ISP would lose its hosting immunity under Article 14 of the E-commerce Directive 2000/31/EC after notification and would risk criminal liability if it did not comply and take the material down.

The Internet Watch Foundation ${ }^{148}$ is also a member of the INHOPE international association of internet hotlines which was founded in 1999 under the EU Safer Internet Action Plan, but transcends the EU- 34 states have a member hotline. ${ }^{149}$ If the content is hosted by an ISP in a country with a Hotline, the Internet Watch Foundation attempts to notify the ISP via the national Hotline or police. However if the content cannot be taken down at source, filtering by UK internet access providers is the only option to avoid (or reduce) exposure to the material. But filtering is only carried out in respect of child sex abuse images.

The blocking of child abuse content is less controversial than, for example, the blocking of online gambling ${ }^{150}$ or copyright infringement ${ }^{151}$ websites, because of the more obvious and serious harms involved. Nevertheless, even the IWF filtering mechanism has been the subject of intense controversy. ${ }^{152}$ Despite the controversy surrounding the filtering of internet content at ISP level, the European institutions are now also considering action in this area: the EU Commission has proposed

\footnotetext{
${ }^{147}$ http://www.iwf.org.uk/public/page.148.htm

148 The IWF has a list of about 100 members, ranging from ISPs, search engines, social networking sites, media companies, mobile phone companies, communication companies, internet security companies, payment providers etc http://www.iwf.org.uk/funding/page.64.htm

149 https://www.inhope.org

150 Italy has attempted to block Maltese gambling websites 2006 Financial Law (Statute 266/2005) Art 1, Paras 535538, http://www.edri.org/edrigram/number4.12/italybetting

${ }^{151}$ Some courts in Europe have ordered a blocking of Pirate Bay IFPI Denmark v DMT2 Bailiff's Court of Frederiksberg (Copenhagen, Denmark), Decision of 5. February 2008, FS 14324/2007

http://www.computerworld.dk/modules/davinci/getfile.php?id=18886\&attachment ; see also http://www.pcworld.com/businesscenter/article/154854/pirate bay still blocked in denmark.html; the Italian Tribunale di Bergamo, Ordinanza of 1. August 2008 N 3277/08 available from http://www.altalex.com/index.php?idnot=42855\&idstr=20; the injunction was later lifted see http://merlin.obs.coe.int/iris/2008/10/article21.en.html

${ }^{152}$ See for example the blocking of the Wikipedia entry on the Scorpion's 1976 album 'Virgin Killer' which featured a naked girl covered by broken glass http://www.guardian.co.uk/commentisfree/2008/dec/09/scorpions-virginkiller-censorship; http://www.openrightsgroup.org/2008/12/iwf-censors-wikipedia-chaos-ensues/ This caused the whole of Wikipedia to be inaccessible from the UK for a short while.
} 
a Directive ${ }^{153}$ to oblige Member States to use filtering mechanisms against child sex abuse websites on 29. March 2010.

Filtering is both over- and under-inclusive, by mistake filtering out 'innocent', non-child abuse content (false positives) or letting through child abuse content (false negatives). ${ }^{154}$ Over-blocking (false positives) has serious negative impacts on the freedom of speech (ie the freedom to impart and receive information). Because of the false negatives and circumvention, it is also true to say that blocking is also only partly effective. ${ }^{155}$

While filtering is a complex and multi-faceted issue which cannot be evaluated in a few paragraphs ${ }^{156}$ this (brief) description of the IWF shows the role of preventative measures in combating obscene content on the internet.

On the one hand the higher risks of the information society can be counterbalanced by technological measures reducing the amount of obscene content available to users. But on the other hand this comes at a price for the freedom of expression and access to information in the online world.

\section{Part V}

\section{Evaluation}

In a liberal society the continuing expansion of the criminal law in new areas is disconcerting, as it restricts individual liberty, restricts the freedom of expression of a majority in order to prevent deviant and harmful conduct by a minority and leads to greater invasion of privacy in the investigation of offences (intrusive and covert surveillance, disclosure of communications and content data, search and seizure of private computers etc). This impact of the criminal law is, of course, deplorable. At the same time it is one-sided to merely point out the restrictions on civil liberties, but it is necessary to weigh this loss of liberty against the increased risks of the information

\footnotetext{
${ }^{153}$ Draft Directive on Combating Sexual Abuse, Sexual Exploitation of Children and Child Pornography COM (2010) 094, available from http://www.europarl.europa.eu/oeil/file.jsp?id=5849492 This will replace Framework Decision 2004/68/JHA

154 I Walden Computer Crimes and Digital Investigations (Oxford University Press 2007) 224; see also the Opinion by Justice Breyer in United States v American Library Association 593 U.S. 194 (2003) 219: the speech harm is largely due to overblocking; see also R Deibert, N Villeneuve 'Firewalls and Power: an Overview of Global State Censorship of the Internet' Chapter 9 in M Klang, A Murray Human Rights in the Digital Age (Glasshouse Press London 2005) 111-124, 113; see also OpenNet Initiative http://opennet.net/about-filtering

${ }^{155}$ W Stol, H Kaspersen (and others) 'Governmental Filtering of Websites: the Dutch Case' 25(3) Computer Law and Security Review 251-262, 254-255; see also U Sieber, M Nolde 'Sperrverfügungen im Internet' Research Report 2008, http://www.kjm-online.de/public/kjm/downloads/juristisches\%20Gutachten\%20Sperrverfuegungen.pdf ${ }^{156}$ For further discussion see W Stol, H Kaspersen (and others) 'Governmental Filtering of Websites: the Dutch Case' 25(3) Computer Law and Security Review 251-262; R Deibert, N Villeneuve 'Firewalls and Power: an Overview of Global State Censorship of the Internet' Chapter 9 in M Klang, A Murray Human Rights in the Digital Age (Glasshouse Press London 2005) 111-124; B Esler 'Filtering, Blocking and Rating: Chaperones or Censorship?' Chapter 8 in M Klang, A Murray Human Rights in the Digital Age (Glasshouse Press London 2005) 99-110; OpenNet Initiative http://opennet.net/research
} 
society. This is a difficult and complex balancing act, but one which is crucial for this debate on the expansion of the criminal law in respect of illegal online content. Much more work needs to be done in this respect, but in this Article I can only briefly outline some of the themes this continuing debate should cover.

One strand of this debate is the protection of human rights under the European Convention of Human Rights (ECHR) ${ }^{157}$, Article 8 (right to privacy) and Article 10 (freedom of expression) and their implementation in the UK by the Human Rights Act 1998. The criminalising of private consumption of pornography for sexual gratification may engage both rights. ${ }^{158}$ However, both Articles $8(2)^{159}$ and $10(2)^{160}$ allow for restrictions of these respective rights provided they are proscribed by law ${ }^{161}$ and comply with the proportionality test, ie are necessary for one of the legitimate objectives. ${ }^{162}$ Both rights can be restricted for the purpose of the protection of morals as well as the rights of others. Hence the ECHR allows restrictions both on grounds of morality and harm to others. In other words the ECHR does not limit justification to a harms based argument and includes protection of morals in its list of possible justification. ${ }^{163}$ Furthermore, the jurisprudence of the European Court of Human Rights gives the Contracting States a wide margin of discretion in respect of their criminal law provisions on obscene content. ${ }^{164}$ While the European Court of Human Rights (ECtHR) has indicated in its jurisprudence that the freedom of expression applies to content that is offending, shocking and

${ }^{157}$ Council of Europe Convention for the Protection of Human Rights and Fundamental Freedoms (ECHR) of 4. November 1950, signed at Rome TS 71 (1953) Cmd 8969; ETS No5 1950

${ }^{158}$ Other rights engaged are Article 7 (prohibition on retroactive criminal laws- certainty in the definition of criminal offences) or Article 1 of the First Protocol (peaceful enjoyment of possessions). For a description of the scope of the meaning of 'private life' in Article 8 and the view that it comprises aspects of a person's sexual life see C Ovey, R White Jacobs \& White European Convention on Human Rights ( $3^{\text {rd }}$ edition Oxford University Press 2002) 221

159 "There shall be no interference by a public authority with the exercise of this right except such as is in accordance with the law and is necessary in a democratic society in the interests of national security, public safety or the economic well-being of the country, for the prevention of disorder or crime, for the protection of health or morals, or for the protection of the rights and freedoms of others."

160 "The exercise of these freedoms, since it carries with it duties and responsibilities, may be subject to such formalities, conditions, restrictions or penalties as are prescribed by law and are necessary in a democratic society, in the interests of national security, territorial integrity or public safety, for the prevention of disorder or crime, for the protection of health or morals, for the protection of the reputation or the rights of others, for preventing the disclosure of information received in confidence, or for maintaining the authority and impartiality of the judiciary." 161 The ECtHR stated in Müller v Switzerland [1991] 13 EHRR 212 in Para 19: 'The need to avoid excessive rigidity and to keep pace with changing circumstances means that many laws are inevitably couched in terms which, to a greater or lesser extent, are vague. Criminal law provisions on obscenity fall within this category.'

${ }^{162}$ See C Ovey, R White Jacobs \& White European Convention on Human Rights ( $3^{\text {rd }}$ edition Oxford University Press 2002) 201

${ }^{163}$ See also C Nowlin 'The Protection of Morals Under the European Convention for the Protection of Human Rights and Fundamental Freedoms' (2002) 24 (1) Human Rights Quarterly 264-286, 264, 279

${ }^{164}$ Müller v Switzerland [1991] 13 EHRR 212 in Paras 32, 35 (depictions of sodomy, fellatio, bestiality in paintings in a public exhibition); Handyside v UK [1979-80] 1 EHRR 737 Paras 48, 52, 59; Laskey v UK (1997) 24 EHRR 39, para 41 (sado-masochistic practices between consulting adults, the criminalisation of which was found to be justified under the protection of health exception- this case was based on the $R v$ Brown case before the House of Lords); see also J Rowbottom 'Obscenity Laws and the Internet: Targeting the Supply and Demand' [2006] Criminal Law Review 97-109, 107-108 
disturbing ${ }^{165}$ and that state interference must be limited to protect the personal autonomy of the individual where an individual consents to sexual activity ${ }^{166}$ the Court has stopped short of limiting interference to the harm principle (which is not surprising given the inclusion of public morality as an exception in the ECHR). ${ }^{167}$

Thus perhaps a more fruitful strand of this debate is the wider normative question of what the limits of the reach of the criminal law should be in a modern liberal society. Traditionally standards of morality prevailing in a given society have been used to justify particular offences prohibiting the publication or distribution of obscene materials. But the position taken here is that vague notions of morality or sensitivity of a majority in relation to offensive content cannot by itself justify the imposition or expansion of criminal offences. In this sense the ECHR should be interpreted afresh to avoid an undue limitation of the freedom of speech and privacy by a vague principle of morality. ${ }^{168}$

The premise here is that only harm-based argumentation can justify the extension of the criminal law. Therefore the crucial question is whether the harms (or risks of harms) stemming from grooming activities, the possession of extreme pornography or NPPIC justify their prohibition given the risks posed by the information society.

As has been discussed above, if a picture is simulated or pure fantasy then no real person has come to harm, in which case the prohibition can only be justified on the basis that such materials allow a person with a predisposition to develop and nurture an obsession which may then lead to real abuse in the offline world (or the consumption of real images, which have already led to harm in the offline world). So much of this question depends whether one believes in the impact of such fantasy materials leading viewers to commit crimes causing real harm. This causal link is by its very nature difficult to establish. Clearly it would be unethical to carry out empirical research exposing test persons to such materials in order to see whether it leads to their committing criminal offences. Given the seriousness of the harm caused by real child sex abuse and the production of extreme pornography featuring murder or $\mathrm{GBH}$, coupled with the easy distribution of these materials via the internet, it may be wise to err on the side of caution. In other words it may be justified to infer that such a causal link may exist, provided there is some evidence pointing to this link (such as the police finding the relevant materials in the possession of persons who have then committed such acts in the real world). Hence a prohibition of this material may still be in accordance with the harm principle. Therefore I argue that, in principle, the criminal prohibition of the possession of extreme pornography and NPPIC is justified by the harm principle. However it is equally important that these offences are defined as narrowly as possible.

\footnotetext{
165 Laskey v UK (1997) 24 EHRR 39, para 56 (Commission), Handyside v UK [1979-80] 1 EHRR 737 Para 49

166 Laskey $v$ UK (1997) 24 EHRR 39, paras 57-60 (Commission), para 44 (Court)

${ }^{167}$ See fn 164; the only exception being ADT v UK Judgment of 31. July 2000 (2001) 31 EHRR 33 where the Court held that the prosecution for gross indecency of a male homosexual for video-taping homosexual activities for private use was an unjustified infringement of Article 8 because of the 'absence of any public health considerations and the purely private nature of the behaviour', para. 38

${ }^{168} \mathrm{C}$ Nowlin 'The Protection of Morals Under the European Convention for the Protection of Human Rights and Fundamental Freedoms' (2002) 24 (1) Human Rights Quarterly 264-286, 265
} 
It is here, in the author's opinion that the UK has moved too far in the direction of suppressing illegal content- in certain respects the expansion of the criminal law has gone too far and is too uncertain. As has been discussed above, some aspects cannot be reconciled with the harm principle. These aspects can be summarised as follows:

The interpretation of the existing legislation by the courts has led to a blurring between the possession, making and publication offences and the courts have been too eager to subsume online activities under both possession and making.

The inchoate offences related to grooming are highly problematic as they rely heavily on the defendant's intention and may therefore put adults having innocent interactions with children at risk.

The definition of extreme pornography should be amended to clearly exclude injuries which do not amount to GBH. In turn, the criminalisation of the possession of other violent, equally harmful materials should at least be considered to arrive at a consistent policy.

Both the criminal offences related to extreme pornography and to NPPIC cause real problems in defining what material is pornographic and what material is art or content with historic or possibly scientific interest. The underlying issue here is that this depends on the mind of the viewer and is therefore inherently subjective. One man's pornography may be another's form of art without any pornographic connotations. For many materials this question will not arise, but there will always be difficult borderline case. The concern here is twofold: first, since artists will not wish to risk prosecution or being made subject to a SOPO (and the social stigma attached with this) this uncertainty suppresses freedom of expression, as personal expression at the borderline will be suppressed. Secondly this puts 'innocent' citizens at risk, who may create, say, a piece of art in the firm belief that it is not pornographic, but whose view on this differs from that of the prosecution and jury. ${ }^{169}$ However it is difficult to see how this delineation problem can be avoided by redrafting the legislation. As has already been pointed out above the legislation prohibiting NPPIC has been drafted narrowly by focusing on certain depictions, rather than just stipulating that the picture must be obscene.

Finally the legislation on NPPIC raises very difficult issues in defining who is a child- if the character is mere fantasy (such as an avatar)- how can the 'age' of that character be defined? A narrower definition would have been preferable here. This could have been achieved by limiting the offence to depictions of persons who clearly show the physical characteristics of a child or by limiting the offence to realistic depictions of a child (rather than a mere 'impression').

\section{Conclusion}

${ }^{169}$ The Director of Public Prosecution must authorise any prosecution of NPPIC 
The proverbial saying 'crime follows opportunity' also holds true for technology. The affordability and availability of cameras created the opportunity to document child sex abuse by photographs and film which necessitate the legislation in the late 1970s and 1980s. The internet then enabled the widespread distribution of this nefarious material across national borders. Convenient and easy access from a person's private home, coupled with the perceived anonymity of the internet, lowered inhibitions and led to an increased demand for obscene content. This increased demand in turn creates a greater risk for children (and other victims) being abused and placed a demand on legislators 'to do something about it'. This in turn has resulted in an expansion of the criminal law in this area: the criminalisation of possession, the inclusion of pseudo- and non-photographic images (virtual child abuse images), the measures against extreme pornography and the inchoate offences of grooming children (for example in chat rooms).

The case law interpreted the relevant legislation widely to cover new modes of distribution and consumption by subsuming acts such as uploading, streaming, viewing and downloading under the existing provisions. As a consequence of this judicial gap-filling adapting the law to new technology there was no lacuna in the criminal law.

Finally because of the greater risks stemming from harmful content, more emphasis is placed on preventative action and this Article has illustrated this preventative principle with the example of the IWF having implemented notice and take down in respect of hosted illegal content and filtering as the last resort in respect of child sex abuse images. The expansion of the criminal law (for example the grooming offences, the possession offences in respect of extreme pornography and virtual child abuse images) also has the goal of preventing harm, by criminalising actions before real world harm occurs.

This expansion of the criminal law is deplorable, but perhaps unavoidable given the risks posed by the internet. The expansion can be justified provided it complies with the harm prevention principle in a proportionate manner. This Article has pointed out where the UK legislation has overshot that line. 
